\title{
sciendo \\ INVOLVEMENT OF GENERATION Z IN THE COMMUNICATION ACTIVITIES OF CLOTHING BRANDS IN SOCIAL MEDIA - THE CASE OF POLAND
}

\author{
ZAANGAŻOWANIE POKOLENIA Z W DZIAŁANIA KOMUNIKACYJNE MAREK ODZIEŻOWYCH \\ W MEDIACH SPOŁECZNOŚCIOWYCH — PRZYPADEK POLSKI
}

\author{
Magda Stachowiak-Krzyżan \\ Poznan University of Economics and Business, Institute of Marketing, Department of Product Marketing \\ al. Niepodległości 10, 61-875 Poznań, Poland \\ magda.stachowiak-krzyzan@ue.poznan.pl O ORCID 0000-0002-4093-2238 \\ DOl: 10.2478/minib-2021-0017
}

\section{ABSTRACT}

Communication activities in social media have a direct impact on shaping consumer behavior, in particular among the youngest group of consumers - Generation Z. This paper analyzes young Polish consumers' interactions with fast-fashion brands on social networking platforms, focusing on their motives for engaging with fashion brands' communication activities on such social media platforms as Facebook, Instagram, Pinterest and YouTube. It presents the empirical findings of a quantitative, pencil-and-paper questionnaire survey carried out among a representative sample of 1000 high-school and university students (representatives of Generation Z) in Poznań, Poland, regarding their perceptions of the profiles of fast-fashion clothing brands on selected social media sites. Principle Component Analysis was used to identify the critical factors determining the involvement of Polish Generation $Z$ representatives in clothing brand profiles (active involvement in the clothing brand profile, observation for measurable benefits and brand loyalty), the main assumptions held by survey participants regarding the clothing brands' motives for being present and active on social media platforms (image/sales goals and cognitive goals) and two groups of the "best" social media activities conducted by clothing brands (entertainment activities and information activities).

Key words: consumer behavior, consumer involvement, social media, fast-fashion brands, clothing, social networks, Generation Z 


\section{ABSTRAKT}

Działania komunikacyjne w mediach społecznościowych mają bezpośredni wpływ na kształtowanie zachowań konsumenckich, w szczególności najmłodszej grupy konsumentów — pokolenia Z. Celem artykułu jest analiza interakcji młodych polskich konsumentów z markami fast-fashion w serwisach społecznościowych, skupiając się na motywach zaangażowania młodych konsumentów w działania komunikacyjne marek modowych realizowane w mediach społecznościowych, takich jak Facebook, Instagram, Pinterest czy Youtube. Artykuł prezentuje empiryczne wyniki badania ilościowego zrealizowanego wśród polskich uczniów i studentów — przedstawicieli pokolenia Z na temat profili marki odzieżowej typu fast-fashion w wybranych serwisach społecznościowych. Przeprowadzono badania na reprezentatywnej grupie 1000 uczniów szkół ponadgimnazjalnych i studentów w Poznaniu. Wyniki posłużyły do zidentyfikowania za pomocą analizy czynnikowej (metoda analiza głównych składowych) krytycznych czynników determinujących zaangażowanie pokolenia Z w profile marek odzieżowych (wyróżniono: aktywne zaangażowanie w profil marki odzieżowej, obserwacja dla mierzalnych korzyści oraz lojalność wobec marki), przesłanek obecności i aktywności marek odzieżowych w mediach społecznościowych z punktu widzenia ich użytkowników (wyróżniono: cele wizerunkowo-sprzedażowe i cele poznawcze) oraz najlepszych działań marek odzieżowych w social media (wyróżniono: działalność rozrywkową i informacyjną).

Słowa kluczowe: zachowania konsumentów, zangażowanie konsumentów, media społecznościowe, marki odzieżowe, sieci społecznościowe, pokolenie Z

JEL: $M 31,111$

\section{Introduction}

With increasing prevalence, social networking platforms are being used by consumers for two-way communication, not only to connect with their friends and family but increasingly to connect with brands. This gives rise to a need for research enabling us to better understand consumers' motives for engaging in social media communication, exploring why people like fanpages and write comments and posts on social media sites. Research is also needed to examine the various opportunities brands have to understand and possibly influence consumers' behavior and actions. Much of the existing research has focused on understanding the impact of social media usage on consumer buying behavior (Nash, 2018; Hollebeek 
\& Solem, 2017; Naylor \& Lamberton, West, 2012; Erkan \& Evans, 2016a; Gunawan\& Huarng, 2015; Park, Lee\& Han, 2007) with a particular emphasis on eWOM (Chu \& Choi, 2011, Erkan \& Evans, 2016b; Wolny \& Mueller, 2013; Wang, Yu \& Wei, 2012). While it is undoubtedly useful for brands to know this, it should be of interest to both academics and practitioners to gain a better understanding of what motivates consumers to engage in communication activities on social networks, and how brands can encourage or discourage such behaviors, which may later lead to purchase.

Social media platforms are nowadays one of the most important communication channels utilized by clothing brands (Bruhn, Schoenmueller \& Schafer, 2012; Mangold \& Faulds, 2009). This is primarily due to their popularity, the possibility of two-way communication (interacting directly with customers) and the ability to communicate using visual content. The last factor is particularly important for the fashion industry. It has been said that social media has become the most important runway for the fashion industry (Apparel Industry, 2010). The power and influence of social media on fashion industry is undoubted (Ahmad, Salman \& Ashiq, 2015). Social media has become one of the most popular tools which creates a link between fashion brand and the consumer. This link not only gives a boost to purchase intentions but also increases two-way communication (Thackeray et al., 2008; Sashi, 2012). Social media platforms are also very valuable tools for consumers. Customers from the clothing industry use social media in their purchase process in several ways. They observe, add clothing brand profiles to friends, gather information about products, look for discounts and information about new collections and trends (Rajapaksha \& Dk, 2019). They treat social media as a source of information and recommendations on clothing products (Chu \& Kim, 2011). Opinions of other people and other consumers published in social media are one of the most important sources of information about clothing products.

Social media are particularly important in the context of young consumers belonging to "Generation $\mathrm{Z}$ " - the digital generation that lives simultaneously online and offline, spending about 4 hours daily online, 
mostly on social media platforms (Stachowiak-Krzyżan\& Ankiel, 2019; Nask, 2019). Generation $\mathrm{Z}$ is one of the most numerous and active groups of social media users, they are called 'digital era leaders' (Berg, 2017). Young people belong to the target group of many clothing brands in the fast-fashion segment. The fast-fashion phenomenon has revolutionized the clothing industry over the past decade (Gabrielli, Baghi\& Codeluppi, 2013). Fast-fashion consumption is predicated on a desire for instant gratification and affordable items with short product life cycle (McNeill $\&$ Venter, 2018). Research suggests that this phenomenon is particularly salient amongst young female consumers, who have little awareness of the social impact of their fashion consumption, but exhibit the highest levels of demand for new fashion products (Morgan \& Birtwistle, 2009). Young people through their outfit express meanings about oneself and create an identity (McNeill \& Moore, 2015). Fashion is psychologically central to teenagers in their self-evaluation and fashion facilitates social inclusion and avoidance of bullying and self-confidence (Isaksen \& Roper, 2012). For young people personal appearance and body image are crucial (Ceballos \& Bejarano, 2018; Jurgensen \& Guesalaga, 2017). Young consumers demonstrate a desire to keep abreast of the latest product and brand trends. Generation $\mathrm{Z}$ have noteworthy purchasing power ( $\mathrm{Su} \&$ Tong, 2018; Parker, Hermans \& Schaefer, 2004). Their purchasing decisions regarding clothing are often influenced by influencers or idols (Majkrzak \& Salerno-Kochan, 2016).

The purpose of this article is to analyze consumers' interactions with fast-fashion brands on social networking platforms, focusing on consumers' motives for engagement in fashion brands communication activities realized in social media such as Facebook, Instagram, Pinterest and Youtube. We use Principle Component Analysis to identify the critical factors determining the involvement of Polish representatives of Generation $\mathrm{Z}$ in clothing brand profiles, the main assumptions held by the survey participants regarding the clothing brands' motives for being present and active on social media platforms, the types of the "best" social media activities conducted by clothing brand. 


\section{Conceptual background}

\section{Consumer involvement in fashion}

The starting point for the development of the concept of customer engagement was the concept of relationship marketing, based on satisfaction and loyalty and building long-term relationships (Baird \& Parasnis, 2011; Sashi 2012). Consumer involvement is perceived as consumer activity in relation to the company (Kumar et al., 2010; Brodie et al., 2011; Vivek, Beatty, Morgan 2012). If the consumer's relationship with the given company is satisfying and based on emotional ties, this leads to the higher level: consumer commitment. The roots of the concept of consumer involvement should be sought in the psychology and theory of organizational behavior (Hollebeek, 2011; Brodie et al., 2013).

Consumer involvement is a multi-dimensional concept. Most often, in the literature, it is presented as a measure of the company's activity (Kumar et al., 2010; Brodie et al., 2011; Vivek, Beatty \& Morgan, 2012). Customer activity is considered in terms of purchases made, incentives directed to the customer, customer conversations about the brand (e.g. in social media) and feedback from the consumer to the company, containing suggestions for changes, in order to improve the level of services provided or product improvement (Zomerdijk, Voss 2010).

Kumar and Pansai (2017) see consumer involvement as a mechanism of influence in the process of creating added value for the company by the customer via his or her direct or indirect participation. Direct participation of the consumer in the creation of added value for the company consists of purchases made by customers, while indirect participation consists of recommendations, consumer conversations about the brand as well as customer feedback and suggestions for the company.

Fashion involvement may be understood as an attachment between consumer and fashion clothing or a relationship between consumer and brand (Su \& Tong 2018). Fashion clothing is commonly considered a highinvolvement product category (Su \& Tong, 2018; Naderi, 2013; Vieria, 2009; O'Cass, 2004), because of its symbolic, expressive or emotional meaning (Miller-Spillman, Reilly, Hunt-Hurst, 2012; O'Cass, 2000). 
Fashion involvement refers to the extent of interest in fashion products and the amount of time, money, and attention spent on fashion products (Park, Kim \& Forney, 2006). Fashion involvement can be defined by the combined impact of several important fashion-related behaviors: fashion innovativeness and time of purchase, fashion interpersonal communication, fashion interest, fashion knowledgeability, fashion awareness and reacting to changing fashion trends (Tiger, Ring \& King, 1976). Fashion involvement is stronger when a product can satisfy valuable utilitarian and hedonic goals, and generate interest, enthusiasm and excitement (Khare, Mishra \& Parveen, 2012). Research has shown that consumers differ in their level of involvement in fashion consumption, with younger consumers exhibiting a higher level of fashion involvement than older consumers (O'Cass, 2004). This causes them to perceive fashion consumption as highly substantial to their self-worth; moreover, they are often fashion innovators or opinion leaders among their peers (O'Cass, 2000; Ogle, Hyllegard \& Yan, 2014).

\section{Social media as a tool to engage consumers}

Social media is defined as a group of online and offline applications that allow for the exchange of user-generated content including the exchange of knowledge and opinions (Kaplan \& Haenlein, 2010). There is a variety of such online information-sharing social media platforms, including social networking platforms (e.g. Facebook), content-sharing platforms (e.g. YouTube, Instagram, Pinterest, Tik-Tok), collaborative websites (e.g. Wikipedia) and microblogging platforms (e.g. Twitter, Tumblr) (Yannopoulou at al., 2019). Nowadays, almost every single company promotes its products or services on social media in some way.

Facebook brand pages have become one of the first channels through which consumers are able to interact with brands in a direct way, by liking, sharing or commenting on brands' posts and messages (Machado, Antunes \& Miranda, 2018). With the emergence of new social networking platforms (e.g. Youtube, Instagram, Pinterest, Tik-Tok, Snapchat and others), their importance in the context of building customer engagement grew (Niyonkomezi \& Kwamboka, 2020; Weitz \& Einwiller, 2018; 
Miranda, Antunes \& Machado, 2016). The like, share and comment features of social media allow anyone to easily interact with a brand. A single brand post can receive thousands of comments from social media sites users all over the world who interact with the brand and other users, providing a platform for dialogue from which information and feedback can be easily obtained. Social-media-using consumers can increasingly integrate and act as co-creators of brand messages. They have a great opportunity to engage and actively participate in communication on the brand's pages on social media. These actions strengthen consumers' ties with brands, turning them into committed fans (Niyonkomezi \& Kwamboka, 2020).

More and more research is being done in the context of consumer engagement in social media. Previous studies in the field of customer engagement in brand communities have focused mostly on the consequences of engagement, including concepts of satisfaction (Bowden 2009), commitment and emotional attachment to the brand (Chan \& Li, 2010), empowerment (Cova \& Pace, 2006; Fuller et al., 2009), consumer value (Gruen et al., 2006; Schau et al., 2009), trust (Casalo et al., 2007; Hollebeek, 2011) and loyalty (Andersen, 2005; Casalo et al., 2007). Currently, various measures are used to explore and gauge consumer engagement. Most often, researchers use the likes, shares and comments index (Vries, Gensler \& Leeflang, 2012; Cvijiki \& Michahelles, 2013).

The main aim of this study, therefore, was to identify the role and importance of content published on social media platforms on the purchasing decisions made by young consumers (Generation $\mathrm{Z}$ ) in the fastfashion clothing market in Poland. More specifically, we set out to study the activity of Generation $\mathrm{Z}$ in social media in the context of decisions to purchase clothing, in particular:

- what activity representatives of Generation $\mathrm{Z}$ display on the profiles of clothing brands in social media;

- key determinants of Generation Z's involvement in the profiles of clothing brands in social media;

- key assumptions held by Generation $\mathrm{Z}$ representatives regarding the presence of clothing brands in social media. 


\section{Study and methods}

We empirically examined the behavior of young consumers of Generation $\mathrm{Z}$ in the context of their use of social media in making purchasing decisions in the fast-fashion market in Poland, using the faceto-face interview method, in the period from June 2017 to January 2018. After an initial assessment, 1,000 correctly completed questionnaires were accepted for further analysis. The research tool was an interview questionnaire prepared and verified in piloting. The measuring instrument consisted of 24 questions, including 6 demographic questions. The survey was anonymous and primarily consisted of closed-end, matrix and ranking questions. In addition, the interview questionnaire contained questions requesting information about the responders' demographic, economic and social characteristics (including sex, age, place of residence, material status, education). The survey was conducted among consumers who declared that they systematically purchase fast-fashion products. The detailed breakdown of the research sample is presented in Table 1.

\section{Table 1. Age, gender and level of education of survey participants (\%)}

\begin{tabular}{l|c|c}
\hline \multicolumn{2}{c|}{ Variables } & Percentage \\
\hline Sex & Female & 58.4 \\
& Male & 41.6 \\
\hline Age & $16-17$ & 2.6 \\
& $18-20$ & 53.1 \\
& $21-23$ & 38.5 \\
& $24-26$ & 5.8 \\
\hline Level of & Upper secondary school (high school) & 15.2 \\
education & State university & 84.8 \\
\hline
\end{tabular}

Nominal and ordinal scales were used in the questionnaire, including the Likert scale, i.e. a bipolar interval scale. The nominal scales were multiple and single choice. The reliability of the construction of the questionnaire was verified by the Alpha-Cronbach test (the coefficient alpha oscillated between 0.7-0.9). In the process of empirical data analysis, the IBM SPSS Statistics tool was used to analyze the results in terms of statistical description, correlation analysis, and factor analysis. 


\section{Result and discussion}

\section{Activity of Generation Z on the profiles of clothing brands in social media}

One of the goals of the study was to identify the activity of Generation $\mathrm{Z}$ on the profiles of clothing brands in social media. The vast majority of the surveyed consumers of Generation $\mathrm{Z}$ in Poland are active in social media on the profiles of clothing brands in the fast-fashion segment. Detailed results of the study in this area are presented in Table 2 and 3 and in Figure 1.

Table 2. Number of clothing brands profiles liked by Generation Z representatives participating in the survey (\%)

\begin{tabular}{l|c|c|c}
\hline \multicolumn{1}{c|}{ Number of profiles } & Total (\%) & Woman (\%) & Men (\%) \\
\hline $1-5$ & 45.9 & 41.8 & 51.7 \\
$6-10$ & 26.9 & 28.4 & 24.9 \\
$11-20$ & 7.9 & 10.3 & 4.6 \\
over 20 & 5.3 & 6.0 & 4.3 \\
I don't remember & 14.0 & 13.6 & 14.5 \\
\hline
\end{tabular}

As Table 2 shows, half of the respondents declared that they "liked" (or, depending on the nomenclature of the specific platform, that they "observed"/"subscribed to" their friends) from 6 to 10 profiles of clothing brands on various social networks. Every fourth respondent was not able to indicate or did not remember how many such profiles they liked. Taking into account gender, it turns out that women like more of such profiles than men. This may be due to the fact that women are usually more interested in fashion and trends, which are topics of interest, passions and hobbies for many women. In addition, there are more clothing brands on the market that offer women's fashion than those with products intended for men, and therefore women have a wider range of brands that they may like.

Another interesting research issue is what motives drive the representatives of Generation Z in Poland when using profiles of clothing brands in social media. 


\section{Figure 1. Survey participants' motives for being a fan} of clothing brand profiles on social media $(\bar{x})$

reaction to satisfaction with a purchased product the ability to systematically track the clothing brand's offerings

the ability to participate in contests

the ability to express one's opinion

the ability to participate in the discussion

searching for information on clothing brands

the ability to obtain a discount

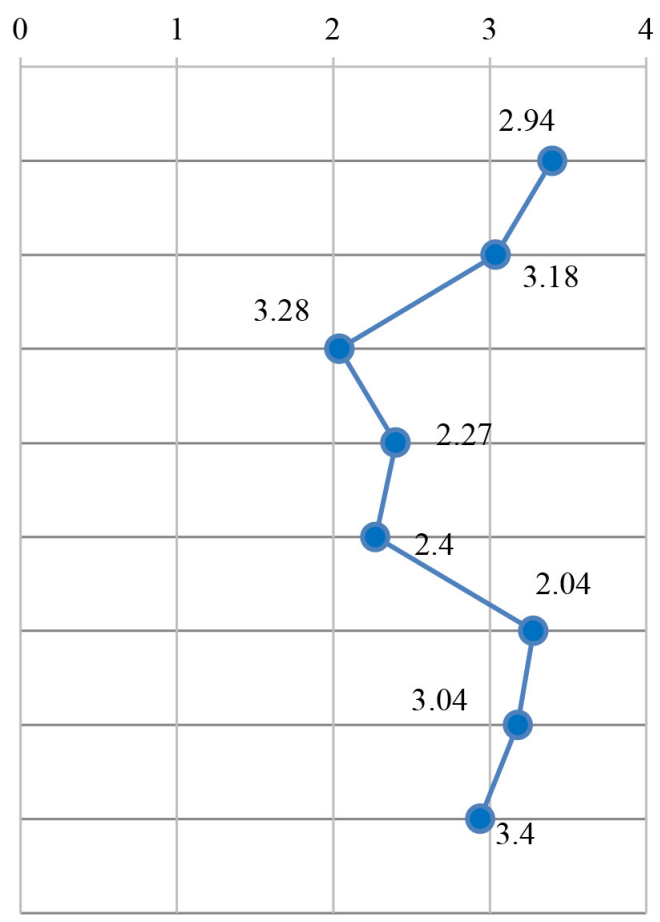

Among the most important reasons why respondents click like on the fanpage of a clothing brand or follow it on Instagram or subscribe on YouTube, the following can be distinguished: eagerness to use a discount coupon $(\bar{x}=3.4)$, which is usually only available to fans or friends of a given brands, the desire to be up to date, follow the offerings of a given clothing brand $(\bar{x}=3.28)$ and, importantly, becoming a fan of a clothing brand is a reaction to respondents' satisfaction with the purchased clothing products of a given brand $(\bar{x}=3.18)$. The least important factors included a desire to participate in the discussion $(\bar{x}=2.04)$ and to express an opinion about a clothing brand or its products $(\bar{x}=2.4)$. This means that young people are more likely to draw upon the opinions of other people, read their recommendations regarding specific products, and at the same time are not eager to publicly express their own reflections and experiences. 
When analyzing the activity of Generation $\mathrm{Z}$ representatives on the profiles of clothing brands in social media, interesting discrepancies between women and men can be observed. They are presented in Table 3.

\section{Table 3. Activity of Generation Z representatives participating} in the survey on the social media profiles of clothing brands (\%)

\begin{tabular}{l|c|c|c}
\hline \multicolumn{1}{c|}{ Activity } & Total (\%) & Woman (\%) & Men (\%) \\
\hline I like / follow / add to my friends & 70.6 & 73.8 & 66.1 \\
I make use of discounts & 69.3 & 74.1 & 62.4 \\
I like photos / entries & 64.7 & 71.9 & 54.4 \\
I take part in contests & 20.1 & 21.8 & 17.8 \\
I express my opinion about the products & 15.5 & 12.7 & 19.5 \\
I send private messages & 14.7 & 16.8 & 11.7 \\
I comment on posts & 10.7 & 11.3 & 9.8 \\
I ask for products on the profile & 7.8 & 8.6 & 6.6 \\
\hline
\end{tabular}

In general, women are more active on clothing brand profiles than men. Women contact clothing brands much more often and more eagerly through private messages, in which they may be looking for support from the service department, information about products, the materials used, their availability, etc. Perhaps when choosing this form of contact, women do not want to make their activities, opinions or purchasing decisions public, they do not want any of their friends to notice their activity. On the other hand, as the survey results show, men are more likely to make public their opinions about clothing products and to interact with other users of social networking sites. Women's activity is less "public" and visible.

\section{The critical factors determining the involvement of the $\mathrm{Z}$ generation in clothing brand profiles}

In order to identify the key determinants of survey participants' involvement in the profiles of clothing brands in social media, factor analysis was used. In accordance with the procedure for verifying the correctness of the application of this method, Bartlett sphericity tests were carried out and the Kaiser-Meyer-Olkin index was calculated (Table 4). 
The obtained KMO value is 0.679 , which indicates that the sampling was adequate for using exploratory factor analysis (it can be assumed that in this case the level of correlation between the factors is high).

\section{Table 4. Results of KMO index and Bartlett's test on survey responses dealing with involvement in clothing brand profiles}

\begin{tabular}{l|l|c}
\hline \multicolumn{2}{l|}{ Kaiser-Meyer-Olkin measure of sampling adequacy } & 0.679 \\
\hline Bartlett sphericity test & Approximate Chi-square value & $\begin{array}{c}998.563 \\
28 \\
\end{array}$ \\
& $\begin{array}{l}\text { Degrees of freedom (df) } \\
\text { Significance }\end{array}$ & .000 \\
\hline
\end{tabular}

Factor analysis was conducted using the method of Principal Component Analysis. Based on Cattell's scree test (a scree plot), three groups of factors were created. Then, adopting a factor loading level of 0.5 as a cut-off point, all the factors were assigned into specific groups (Table 3). The three factors combined explain nearly $57 \%$ of common variance: the first one explains $29 \%$, the second $15 \%$ and the third $13 \%$.

Table 5. The most important factors motivating participants to be active on the profiles of clothing brands in social media (the value of factor loadings obtained by factor analysis)

\begin{tabular}{l|c|c|c}
\hline \multirow{2}{*}{$\begin{array}{c}\text { Factors motivating paricipants to be active } \\
\text { on the profiles of clothing brands }\end{array}$} & \multicolumn{2}{c}{ Components/values of factor loadings } \\
\cline { 2 - 4 } & $\mathbf{1}$ & $\mathbf{2}$ & $\mathbf{3}$ \\
\hline possibility of using a discount & - & - & 0.734 \\
searching for information on clothing brands & - & - & 0.764 \\
the opportunity to participate in the discussion (about the brand) & - & 0.705 & - \\
the opportunity to express one's opinion & 0.537 & - & - \\
the opportunity to participate in contests & 0.865 & - & - \\
the possibility of systematic tracking of the clothing brand's offerings & 0.849 & - & - \\
reaction to satisfaction with the purchased product & - & - & - \\
attachment to a clothing brand & - & 0.743 & - \\
\hline
\end{tabular}

The results of factor analysis shown in Table 5 allow us to identify the following key determinants of young consumers' involvement in the profiles of clothing brands in social media: 
- Factor 1: active involvement in the clothing brand profile (the opportunity to express one's opinion, the opportunity to participate in the contests, the possibility of systematic tracking of the clothing brand's offerings);

- Factor 2: observation for measurable benefits (possibility of obtaining a discount, searching for information on clothing brands);

- Factor 3: brand loyalty (the opportunity to participate in the discussion, attachment to a clothing brand).

In summary, for young consumers, the main reasons for liking clothing brand profiles is the desire to be actively involved in the clothing brand profile. Secondly, young consumers are involved in clothing brand profiles because they see additional benefits, e.g. discount coupons. Thirdly, young consumers are involved in clothing brand profiles to show their loyalty to the clothing brand, which may be the result of positive experiences with the clothing product.

\section{The critical factors determining assumptions about clothing brands' motives for their social media presence and activity}

Another research goal was to identify the key assumptions held by the Generation $\mathrm{Z}$ representatives participating in the survey about the clothing brands' motives for being present and active in social media. For this, we again used factor analysis. The procedure was the same as described in section 3.2. First, the results were subjected to Bartlett's sphericity test and the KMO (Kaiser-Mayer-Olkin) measure was calculated. Again, both the obtained measurements confirmed the adequacy of the sample for performing factor analysis (Table 6).

Then the analysis was again conducted using the method of Principal Component Analysis. Based on Cattell's scree test (a scree plot), two groups of factors were created. Then, adopting a factor loading level of 0.5 as a cut-off point, all the factors were assigned into specific groups (Table 7). The two factors combined explain nearly $52 \%$ of common variance: the first one explains $34 \%$ and the second $18 \%$. 
Table 6. Results of KMO index and Bartlett's test on survey responses dealing with assumptions about clothing brands' motives for their social media presence and activity

\begin{tabular}{l|l|c}
\hline \multicolumn{2}{l|}{ Kaiser-Meyer-Olkin measure of sampling adequacy } & 0.722 \\
\hline Bartlett sphericity test & Approximate Chi-square value & 900.220 \\
& Degrees of freedom (df) & 21 \\
& Significance & .000 \\
\hline
\end{tabular}

Table 7. The most important factors underlying participants' assumptions about clothing brands' motives for their social media presence and activity

\begin{tabular}{l|c|c}
\hline \multicolumn{1}{c|}{$\begin{array}{c}\text { Factors underlying participants' assumptions } \\
\text { about clothing brands' motives for their social media } \\
\text { presence and activity }\end{array}$} & $\begin{array}{c}\text { Components/ } \\
\text { /values of factor loadings }\end{array}$ \\
\cline { 2 - 3 } $\begin{array}{l}\mathbf{2} \\
\text { taking care of the brand image }\end{array}$ & 0.727 & \\
boosting product sales & 0.818 & - \\
acquiring new customers & 0.713 & - \\
learning about customer reviews or talking to customers & -560 \\
imitating / following the competition & 0.707 & \\
obtain information about clients & 0.756 & \\
looking for new employees & & \\
\hline
\end{tabular}

The results of factor analysis included in Table 7 allow to identify the following key factors underlying participants' assumptions about clothing brands' motives for their social media presence and activity:

- Factor 1: image/sales goals (working to ensure the brand image, boosting product sales, acquiring new customers);

- Factor 2: cognitive goals (imitating/following the competition, obtaining information about clients, looking for new employees).

In the opinion of young consumers surveyed, the main motives assumed to be driving the presence of fast-fashion clothing brands in social media are image and sales goals, i.e. striving to improve sales results, to 
attract new customers or to care for and project the brand image. The second important type of assumed motive are cognitive goals, manifested in the desire to look for employees or obtain information about their clients.

\section{The critical factors determining the best clothing brand activities in social media}

The last goal was to identify factors which determine the best clothing brand activities in social media. Once again, the procedure was the same as described in section 3.2 and 3.3. Firstly, Bartlett's sphericity test and the KMO (Kaiser-Mayer-Olkin) measure were calculated. Again, both measurements confirmed the sampling adequacy for performing factor analysis (Table 8).

Table 8. Results of KMO index and Bartlett's test on survey responses dealing with the best clothing brand activities in social media

\begin{tabular}{l|l|c}
\hline \multicolumn{2}{l|}{ Kaiser-Meyer-Olkin measure of sampling adequacy } & .660 \\
\hline Bartlett sphericity test & Approximate Chi-square value & 900.220 \\
& Degrees of freedom (df) & 21 \\
& Significance & .000 \\
\hline
\end{tabular}

Next, Principal Component Analysis was applied. Based on Cattell's scree test (a scree plot), two groups of factors were created. Then, adopting a factor loading level of 0.5 as a cut-off point, all the factors were assigned into specific groups (Table 9). The two factors combined explain nearly $46 \%$ of common variance: the first one explains $28 \%$, the second $18 \%$.

The results of the factor analysis listed in Table 9 identify the following key determinants behind the presence and activity of clothing brands:

- Factor 1: entertainment activities (posting information from the clothing industry, conducting contests, providing games and applications); 
- Factor 2: information activities (announcing new clothing collections and new products in the assortment, announcing special offers (discounts, sales, coupons), publishing photos and video materials about products and clothing brand).

Table 9. The most important factors determining best clothing brand activities in social media

\begin{tabular}{l|c|c}
\hline \multicolumn{1}{c}{$\begin{array}{c}\text { Factors determining best clothing brand } \\
\text { activities in social media }\end{array}$} & \multicolumn{2}{c}{$\begin{array}{c}\text { Components/values } \\
\text { of factor loadings }\end{array}$} \\
\cline { 2 - 3 } & $\mathbf{1}$ & $\mathbf{2}$ \\
\hline announcing new clothing collections and new products in the assortment, & - & 0.800 \\
announcing special offers (discounts, sales, coupons) & - & 0.665 \\
publishing photos and video materials about products and clothing brand & - & 0.500 \\
customer support & - & - \\
posting information from the clothing industry (regarding fashion) & 0.632 & 0.614 \\
holding contests & 0.726 & \\
providing games and applications & & \\
\hline
\end{tabular}

For young consumers, the most interesting activities undertaken by clothing brands in social media are entertainment activities, including conducting contests and providing games and applications. The second group of valuable activities are information activities, consisting in providing information about new clothing collections as well as special offers and sales.

\section{Conclusions}

Social media platforms are a key channel of marketing communication for clothing companies from the fast-fashion segment, in the process of the purchasing decisions made by young consumers. Research has shown that social media platforms are used by young consumers at different stages of the decision-making process. They not only generate needs, but also constitute a valuable source of inspiration at the stage of searching for 
opportunities to satisfy a need. Our results indicate that women add more clothing brand profiles to their lists of friends than men do. In addition, women are more active on the profiles of clothing brands in social media, are more likely to make use of discount coupons, more often like and comment on published content and share it, take part in contests, add posts with inquiries and send private messages. In turn, men are more likely to express their opinion about products and enter into discussions with other users of social media. Gender also differentiates the opinions of the respondents towards the profiles of clothing brands in social media. Women, despite the fact that they treat these profiles as another advertising medium, evaluate them positively, as useful and interesting. Social media platforms alter the roles of buyers and sellers and the relationships between them.

The use of social media allows fans to connect and interact with other users, increasing mutual satisfaction and advocacy for brands. Seeking insight into customers' involvement, our study analyzed the influencing factors in terms of Generation Z's involvement on the social media profiles of fashion brands. From the point of view of companies in the clothing industry, customer engagement turns customers into fans. They become brand ambassadors, more attractive, more profitable and regular customers. Customers play an important role in the value-adding process as co-creators of content and value. Customer involvement is essential to brands for retaining them and turning them into loyal customers. On the other hand, from the point of view of customers, their commitment displayed in social media can be the result of several reasons: personal motives, a desire to achieve additional benefits and as an expression of loyalty to a fashion brand.

The results of this study may serve as a valuable source of information for brand managers who are responsible for designing and implementing brand communication activities in social media. The findings may help fashion brands to better understand how to influence peer-to-peer communications and how to engage their fans on social media. Moreover, the results of this study may lay the foundation for developing a strategy to increase customer satisfaction. Marketers should continually strive to learn more about what representatives of Generation $\mathrm{Z}$ - both in Poland and elsewhere - expect and what content they desire. 


\section{Limitations and future research directions}

This study has several limitations. Firstly, the sample is limited. The results cannot be generalized to Polish consumers overall, due to the study population being limited to young people. Although this particular group of consumers is playing an important role in the clothing market, the results do not provide a comprehensive description of consumer engagement. Therefore, further research should also be carried out to include other consumer groups and other generations.

Secondly, the test results cannot be generalized to all clothing brands on the market from various segments. The survey covered the fast-fashion clothing segment, a segment which has its own distinctive traits. For this reason, the survey results should not be generalized to other segments of the clothing market.

It should also be noted that the study reported herein only considered selected social media sites popular in the clothing industry, which are often used by young people in Poland (Facebook, Snapchat, Instagram, Youtube and Pinterest). It would be interesting to continue the study, examining the communication activities of clothing brands on individual, specific social networking sites, taking into account their distinctive aspects, which would allow better insight to be gained into consumer involvement. Moreover, it would be very interesting to conduct a similar study considering the Covid-19 pandemic and its impact on consumer behavior.

\section{References}

1. Ahmad, N. Salman, A., \& Ashiq, R. (2015). The impact of social media on fashion industry: Empirical investigation from Karachiites. Journal of Resources Development and Management 7, 1-7.

2. Andersen, P. H. (2005). Relationship marketing and brand involvement of professionals through web-enhanced brand communities: The case of Coloplast. Industrial Marketing Management, 34(1), 39-51. DOI: https://doi.org/10.1016/j.indmarman.2004.07.002

3. Apparel Magazine. (2010). How social media is revolutionizing the apparel industry: One message at a time. Apparel Magazine, 52(4), 1-6.

4. Baird, C. H., \& Parasnis, G. (2011). From social media to social customer relationship management. Strategy and Leadership, 39(5). DOI: 10.1108/10878571111161507 
5. Berg, L. (2017). Young consumers in the digital era: The selfie effect. International Journal of Consumer Studies, 42, 379-388. DOI: 10.1111/ijcs.12431

6. Bowden, J. L. H. (2009). The process of customer engagement: A conceptual framework. Journal of Marketing Theory and Practise, 17(1), 63-74. DOI: 10.2753/MTP10696679170105

7. Brodie, R. J., Hollebeek, L. D., Jurić, B., \& Ilić, A. (2011). Customer engagement: Conceptual domain, fundamental propositions, and implications for research. Journal of Service Research, 17(3), 1-20. DOI: https://doi.org/10.1177/1094670511411703

8. Brodie, R. J., Ilić, A., Jurić, B., \& Hollebeek, L. D. (2013). Consumer engagement in a virtual brand community: An exploratory analysis. Journal of Business Research, 66(1), 105-114. https://doi.org/10.1016/j.jbusres.2011.07.029

9. Bruhn, M., Schoenmueller, V., \& Schafer, D. B. (2012). Are social media replacing traditional media in terms of brand equity creation? Management Research Review, 35(9), 770-790. DOI: 10.1108/01409171211255948

10. Casalo, L., Flavian, C., \& Guinaliu, M. (2007). The impact of participation in virtual brand communities on consumer trust and loyalty: The case of free software. Online Information Review, 31(6), 775-792. DOI: 10.1108/14684520710841766

11. Ceballos, L. M., \& Bejarano, M. (2018). Value segmentation of adolescents: A performance of appearance. International Journal of Fashion Design, Technology and Education, 11(2), 148-159. DOI: 10.1080/17543266.2017.1352039

12. Chan, K. W., \& Li, S. Y. (2010). Understanding consumer-to-consumer interactions in virtual communities: The salience of reciprocity. Journal of Business Research, 63, 1033-1040. https://doi.org/10.1016/j.jbusres.2008.08.009

13. Chu, S. C., \& Choi, S. M. (2011). Electronic word-of-mouth in social networking sites: A cross-cultural study of the United States and China. Journal of Global Marketing, 24(3), 263-281. DOI: https://doi.org/10.1080/08911762.2011.592461

14. Chu, S., Kim, Y. (2011). Determinants of consumer engagement in electronic. International Journal of Advertising, 30(1), 47-75. DOI: https://doi.org/10.2501/IJA-30-1-047-075

15. Cova, B., \& Pace, S. (2006). Brand community of convenience products: New forms of customer empowerment-the case "My Nutella the Community". European Journal of Marketing, 40(9/10), 1087-1105. DOI: 10.1108/03090560610681023

16. Cvijikj, I. P., \& Michahelles, F. (2013). Online engagement factors on Facebook brand pages. Social Network Analysis and Mining, 3(4), 843-861. DOI: 10.1007/s13278-013-0098-8

17. Erkan, I., \& Evans, C. (2016a). Social media or shopping websites? The influence of eWOM on consumers' online purchase intentions. Journal of Marketing Communications 24(6), 1-17. DOI: 10.1080/13527266.2016.1184706

18. Erkan, I., \& Evans, C. (2016b). The influence of eWOM in social media on consumers' purchase intentions: An extended approach to information adoption. Computers in Human Behaviour 61, 47-55. DOI: 10.1016/j.chb.2016.03.003

19. Fuller, J., Muhlbacher, H., Matzler, K., \& Jawecki, G. (2009). Consumer empowerment through Internet-based co-creation. Journal of Management Information Systems, 26(3),71-102. https://doi.org/10.2753/MIS0742-1222260303

20. Gabrielli, V., Baghi, I., \& Codeluppi, V. (2013). Consumption practices of fast fashion products: A consumer-based approach. Journal of Fashion Marketing and Management, 17(2), 206-224. DOI: https://doi.org/10.1108/JFMM-10-2011-0076 
21. Gruen, T. W., Osmonbekov, T., \& Czaplewski, A. J. (2006). EWOM: The impact of customer-to-customer online know-how exchange on customer value and loyalty. Journal of Business Research, 59(4), 449-456. DOI: https://doi.org/10.1016/ j.jbusres.2005.10.004

22. Gunawan, D.D., \& Huarng, K. H. (2015). Viral effects of social network and media on consumers' purchase intention. Journal of Business Research, 68(11), 2237-2241. DOI: 10.1016/j.jbusres.2015.06.004

23. Hollebeek, L. D. (2011). Demystifying customer brand engagement: Exploring the loyalty nexus. Journal of Marketing Management, 27(7/8), 785-807. DOI: 10.1080/0267257X.2010.500132

24. Hollebeek, L. D., \& Solem, B. A. (2017). The consumer engagement/return on social media engagement interface: Development of a conceptual model. In Bikramjit Rishi, \& Subir Bandyopadhyay (eds.), Contemporary Issues in Social Media Marketing, (pp. 132-148). DOI: $10.4324 / 9781315563312$

25. Isaksen, K. J., \& Roper, S. (2012). The commodification of self-esteem: Branding and British teenagers. Psychology \& Marketing, 29(3), 117-135. DOI: 10.1002/mar.20509

26. Jurgensen, K, \& Guesalaga, R. (2017). Young consumers' innovativeness in apparel choices: A model including consumer self-confidence. International Journal of Consumer Studies, 42, 255-263. DOI: 10.1111/ijcs.12414

27. Kaplan, A. M., Haenlein, M. (2010). Users of the world, unite! The challenges and opportunities of Social Media. Business Horizons, 53(1), 59-68. DOI:.org/10.1016/ j.bushor.2009.09.003

28. Khare, A., Mishra, A., \& Parveen, C. (2012). Influence of collective self esteem on fashion clothing involvement among Indian women. Journal of Fashion Marketing and Management, 16(1), 42-63. DOI: https ://doi.org/10.1108/13612 021211203023

29. Kumar, V., Aksoy, L., Donkers, B., Venkatesan, R., Wiesel, T., \& Tillmanns, S. (2010). Undervalued or overvalued customers: Capturing total customer engagement value. Journal of Service Research, 13(3), 297-310. DOI: https://doi.org/10.1177/1094670510375602

30. Kumar, V., \& Pansari, A. (2017). Customer engagement: The construct, antecedents, and consequences. Journal of the Academic Marketing Science, 45(3). DOI: 10.1007/s11747-016-0485-6

31. Machado, A., Antunes, A. C., \& Miranda, S. L. (2018). Consumer engagement: The amplifying effect of comments. Conference Papers: 5th European Conference on Social Media - ECSM 2018 at Limerick, Ireland.

32. Majkrzak, A. X., \& Salerno-Kochan, R. (2016). The perception of apparel quality in the aspect of young consumers' buying behaviors. Part 1. Towaroznawcze Problemy Jakości, 3(48), 22-30.

33. Mangold, W. G., \& Faulds, D. J. (2009). Social media: The new hybrid element of the promotion mix. Business Horizons, 50(4), 357-365. DOI: https:/doi.org/ 10.1016/j.bushor.2009.03.002

34. McNeill, L., \& Moore, R. (2015). Sustainable fashion consumption and the fast fashion conundrum: Fashionable consumers and attitudes to sustainability in clothing choice. International Journal of Consumer Studies, 39, 212-222. DOI: 10.1111/ijcs.12169

35. McNeill, L., \& Venter, B. (2018). Identity, self-concept and young women's engagement with collaborative, sustainable fashion consumption models. International Journal of Consumer Studies, 43, 368-378. DOI: 10.1111/ijcs.12516 
36. Miller-Spillman, K. A., Reilly, A., \& Hunt-Hurst, P. (2012). The meanings of dress. New York, Fairchild Publications.

37. Miranda, S. L., Antunes, A. C., \& Machado, A. (2016). Looking beneath the surface: How brands led to consumer engagement in Social Media. Conference Papers: 22nd IAMB Conference.

38. Morgan, L.R., \& Birtwistle, G. (2009). An investigation of young fashion consumers' disposal habits. International Journal of Consumer Studies, 33, 190-198. DOI: 10.1111/ j.1470-6431.2009.00756.x

39. Naderi, I. (2013). Beyond the fad: A critical review of consumer fashion involvement. International Journal of Consumer Studies, 37(1), 84-104. DOI: https ://doi.org/ 10.1111/j.1470-6431.2011.01041.x

40. Nash, J. (2018). Exploring how social media platforms influence fashion consumer decisions in the UK retail sector. Journal of Fashion Marketing and Management 23(1), 82-103. DOI: 10.1108/JFMM-01-2018-0012

41. Nask. (2019). Raport z badań „Nastolatki 3.0”. Warszawa: Państwowy Instytut Badawczy.

42. Naylor, R. W., Lamberton, C. P., \& West, P. M. (2012). Beyond the "like" button: The impact of mere virtual presence on brand evaluations and purchase intentions in social media settings. Journal of Marketing, 76(6), 105-120. DOI: https://doi.org/ 10.1509/jm.11.0105

43. Niyonkomezi, J., \& Kwamboka, J. (2020). Effect of brand communities on consumer engagement and trust. International Journal of Research in Business and Social Science, 9(4), 244-252. DOI: 10.20525/ijrbs.v9i4.719

44. O'Cass, A. (2000). An assessment of consumers product, purchase decision, advertising and consumption involvement in fashion clothing. Journal of Economic Psychology, 21(5), 545-576. DOI: https ://doi.org/10.1016/S0167-4870(00)00018-0

45. O'Cass, A. (2004). Fashion clothing consumption: Antecedents and consequences of fashion clothing involvement. European Journal of Marketing, 38(7), 869-882. DOI: https ://doi.org/10.1108/03090 560410539294

46. Ogle, J. P., Hyllegard, K. H., \& Yan, R. N. (2014). An investigation of mothers' and tween daughters' clothing preferences and purchase intentions toward a prosocial clothing company. Journal of Fashion Marketing and Management: An International Journal, 18(1), 70-84. DOI: https ://doi.org/10.1108/JFMM-09-2012-0060

47. Park, E. J., Kim, E. Y., \& Forney, J. C. (2006). A structural model of fashion-oriented impulse buying behavior. Journal of Fashion Marketing and Management, 10, 433-446.

48. Park, D. H., Lee, J., \& Han, I. (2007). The effect of on-line consumer reviews on consumer purchasing intention: The moderating role of involvement. International Journal of Electronic Commerce 11(4), 125-148. DOI: https://doi.org/10.2753/JEC10864415110405

49. Parker, R. S., Hermans, Ch. M., \& Schaefer, A. D. (2004). Fashion consciousness of Chinese, Japanese and American teenagers. Journal of Fashion Marketing and Management, 8(2), 176-186. https://doi.org/10.1108/13612020410537870

50. Rajapaksha, L. B., \& Dk, T. (2019). The Influence of Facebook brand page on consumer purchase intention with reference to fashion retailing industry. Sri Lanka Journal of Marketing, 5(1), 55-101. 
51. Sashi, C. (2012). Customer engagement, buyer-seller relationships, and social media. Management Decision, 50(2), 253-272. DOI: 10.1108/00251741211203551

52. Schau, H. J., Muniz A. M., \& Arnould, E.J. (2009). How brand community practices create value. Journal of Marketing, 73:30-51. DOI: 10.1509/jmkg.73.5.30

53. Stachowiak-Krzyżan, M., \& Ankiel, M. (2019). Behaviours of young consumers in a virtual environment on the example of the fashion industry. Annales Universitatis Mariae CurieSktodowska, Sectio H Oeconomia 53(1), 89-97. DOI:10.17951/h.2019.53.1.89-97

54. Su, J. Tong, X. (2018). An empirical study on Chinese adolescents' fashion involvement. International Journal of Consumer Studies, 44, 232-242. DOI: 10.1111/ijcs.12564

55. Thackeray, R., Neiger, B., Hanson, C., \& McKenzie, J. (2008). Enhancing promotional strategies within social marketing programs: Use of Web 2.0 social media. Health Promotion Practice, 9(4), 338-343. DOI: 10.1177/1524839908325335

56. Tiger, D. J., Ring, L. J., \& King, C.W. (1976). Fashion involvement and buying behavior: A methodological study. Advances in Consumer Research, 03, 46-52.

57. Vieria, V. A. (2009). An extended theoretical model of fashion clothing involvement. Journal of Fashion Marketing and Management, 13(2),179-200. DOI: 10.1108/ 13612020910957707

58. Vivek, S. D., Beatty, S. E., \& Morgan, R. M. (2012). Customer engagement: Exploring customer relationships beyond purchase. The Journal of Marketing Theory and Practice, 20(2), 127-145. DOI: 10.2753/MTP1069-6679200201

59. Vries, L. J., Gensler, S., \& Leeflang, P. (2012). Popularity of brand posts on brand fan pages: An investigation of the effects of social media marketing. Journal of Interactive Marketing 26(2), 83-91. DOI: 10.1016/j.intmar.2012.01.003

60. Wang, X., Yu, C., \& Wei, Y. (2012). Social media peer communication and impacts on purchase intentions: A consumer socialization framework. Journal of Interactive Marketing, 26(4), 198-208. DOI: https://doi.org/10.1016/j.intmar.2011.11.004

61. Weitzl, W. J., \& Einwiller, S. (2018). Consumer engagement in the digital era. In K. A. Johnston, \& M. Taylor (eds.), The handbook of communication engagement (pp. 453-473). DOI: 10.1002/9781119167600.ch31.

62. Wolny, J., \& Mueller, C. (2013). Analysis of fashion consumers' motives to engage in electronic word-of-mouth communication through social media platforms. Journal of Marketing Management, 29(5-6), 562-583. DOI:10.1080/0267257X.2013.778324

63. Yannopoulou, N., Liu, M. J., Bian, X., \& Heath, T. (2019). Exploring social change through social media: The case of the Facebook group Indignant Citizens. International Journal of Consumer Studies, 43(4), 348-357. DOI: 10.1111/ijcs.12514

64. Zomerdijk, L. G., \& Voss, Ch. A. (2010). Service design for experience-centric services. Journal of Service Research, 13(1), 67-82. DOI: 10.1177/1094670509351960

Magda Stachowiak-Krzyżan, PhD Eng. - Ph.D. in economic sciences, Assistant Professor at the Poznań University of Economics and Business, where she is employed in the Product Marketing Department at the Institute of Marketing. Her research and teaching interests focus on consumer behavior, social marketing, marketing communication and the clothing market in social media. 